\title{
Muzolimine: a new high-ceiling diuretic suitable for patients with advanced renal disease
}

\author{
ANTONIO DAL CANTON, DOMENICO RUSSO, RICCARDO GALLO, GIUSEPPE CONTE, \\ VITTORIO E ANDREUCCI
}

\begin{abstract}
Muzolimine was administered by mouth to 24 patients with creatinine clearances ranging from 4 to $28 \mathrm{ml} / \mathrm{min}$ to treat oedema or hypertension, or both. In four of these 24 patients muzolimine was given after intravenous high-dose frusemide had been unsuccessful. Muzolimine significantly increased urine volume and excretions of sodium, chloride, and potassium ions. Its diuretic efficacy was further shown by a mean reduction in body weight of $8 \%$ and by the disappearance of oedema in all affected patients, even those refractory to intravenous frusemide. No rebound phenomenon was observed after the drug was stopped. Mean blood pressure was reduced in all hypertensive patients. Blood pressure was restored to normal in five out of seven patients treated with muzolimine alone and 10 out of 11 in whom muzolimine had been added to previously unsatisfactory antihypertensive treatment. Muzolimine was well tolerated by all patients.

Muzolimine appears to be the diuretic of choice when treating patients with advanced renal disease.
\end{abstract}

\section{Introduction}

In advanced renal failure diuretic treatment is hampered by the great loss of functioning nephrons as well as by the difficulty in further decreasing tubular reabsorption of sodium (and water) in residual nephrons; in residual nephrons a "spontaneous" intensive diuresis already occurs due to extracellular volume expansion or the rise in osmotic load, or both. ${ }^{1}$ Only high-

Department of Nephrology, Second Faculty of Medicine, University of Naples, Italy

ANTONIO DAL CANTON, MD, vice-director

DOMENICO RUSSO, MD, assistant

RICCARDO GALLO, MD, intern

GIUSEPPE CONTE, MD, assistant

VITTORIO E ANDREUCCI, MD, professor of nephrology and director ceiling diuretics, such as ethacrynic acid or frusemide, may stil be effective. ${ }^{2}$ Disadvantages of these drugs, however, are the frequent need for intravenous administration of high, potentially toxic, doses; the short duration of action; and the so-called "rebound phenomenon," whereby urine flow and sodium output often drop below control values as soon as the diuretic effect is exhausted. ${ }^{3}$

Muzolimine is a new potent diuretic with no structural similarity to currently available diuretics. Chemically it is 3-amino-1-(3, 4 dichlor-

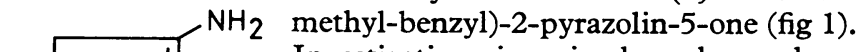
Investigations in animals and man have located its site of action in the ascending limb of Henle's loop. ${ }^{6}$ High-peak plasma concentrations may be obtained soon after oral administration; its long-lasting effect has been attributed to a prolonged half life.

The combination of high-ceiling activity with a long duration of action without the rebound phenomenon suggests that muzolimine may usefully be substituted for other potent diuretics in the treatment of salt retention in patients with renal failure.

FIG 1-Structural formula of muzolimine.

This paper represents the first report on the use of muzolimine in patients with advanced renal failure.

\section{Patients and methods}

Our studies were performed in 24 patients with chronic renal failure (creatinine clearance below $30 \mathrm{ml} / \mathrm{min}$ ) admitted to the nephrology unit. All patients required diuretic treatment because of oedema or hypertension, or both, and gave informed consent to the study.

\section{EFFICACY OF MUZOLIMINE}

The efficacy of muzolimine was studied in 20 patients; pertinent clinical data are summarised in table I. In each patient protein and sodium intakes were kept constant during the study. Before admin- 
TABLE I-Clinical data on patients in whom efficacy of muzolimine was studied

\begin{tabular}{|c|c|c|c|c|c|c|c|c|}
\hline $\begin{array}{l}\text { Case } \\
\text { No }\end{array}$ & Sex & $\underset{\text { (years) }}{\text { Age }}$ & Renal disease & $\begin{array}{c}\text { Creatinine } \\
\text { clearance } \\
(\mathrm{ml} / \mathrm{min})\end{array}$ & Oedema* & $\begin{array}{c}\text { Blood } \\
\text { pressure } \\
(\mathrm{mm} \mathbf{H g})\end{array}$ & Other conditions & Drugs \\
\hline $\begin{array}{r}1 \\
2 \\
3 \\
4 \\
5 \\
6 \\
7 \\
8 \\
9 \\
10 \\
11 \\
12 \\
13 \\
14 \\
15 \\
16 \\
17 \\
18 \\
19 \\
20\end{array}$ & $\begin{array}{l}M \\
M \\
M \\
F \\
F \\
M \\
M \\
M \\
M \\
M \\
M \\
M \\
M \\
M \\
M \\
F \\
M \\
M \\
F \\
M\end{array}$ & $\begin{array}{l}49 \\
49 \\
48 \\
72 \\
69 \\
55 \\
49 \\
52 \\
66 \\
51 \\
59 \\
58 \\
68 \\
71 \\
32 \\
41 \\
56 \\
57 \\
32 \\
49\end{array}$ & $\begin{array}{l}\text { Amyloidosis } \\
\text { Glomerulonephritis } \\
\text { Glomerulonephritis } \\
\text { Pyelonephritis } \\
\text { Nephrolithiasis } \\
\text { Glomerulonephritis with nephrotic syndrome } \\
\text { Malignant hypertension } \\
\text { Kimmelstiel-Wilson disease } \\
\text { Glomerulonephritis with nephrotic syndrome } \\
\text { Glomerulonephritis with nephrotic syndrome } \\
\text { Nephrosclerosis } \\
\text { Kimmelstiel-Wilson disease } \\
\text { Nephrosclerosis } \\
\text { Glomerulonephritis with nephrotic syndrome } \\
\text { Malignant hypertension } \\
\text { Chronic rejection } \\
\text { Glomerulonephritis with nephrotic syndrome } \\
\text { Malignant hypertension } \\
\text { Glomerulonephritis } \\
\text { Amyloidosis }\end{array}$ & $\begin{array}{r}21 \\
13 \\
8 \\
6 \\
19 \\
25 \\
13 \\
9 \\
20 \\
28 \\
17 \\
27 \\
22 \\
22 \\
25 \\
4 \\
25 \\
5 \\
12 \\
7\end{array}$ & $\begin{array}{c}+ \\
++ \\
++ \\
+++ \\
+++ \\
+++ \\
++ \\
+ \\
++ \\
++ \\
+++ \\
+++ \\
+++ \\
++ \\
++ \\
++\end{array}$ & $\begin{array}{l}130 / 80 \\
190 / 100 \\
170 / 100 \\
200 / 100 \\
140 / 100 \\
260 / 120 \\
200 / 130 \\
205 / 100 \\
160 / 80 \\
210 / 110 \\
175 / 100 \\
180 / 100 \\
180 / 120 \\
130 / 70 \\
185 / 100 \\
160 / 100 \\
255 / 120 \\
190 / 130 \\
175 / 100 \\
175 / 105\end{array}$ & $\begin{array}{l}\text { Cardiac failure } \\
\text { Diabetes, cardiac failure } \\
\text { Diabetes, cardiac failure }\end{array}$ & $\begin{array}{l}\text { Digoxin, methyldopa } \\
\text { Clonidine } \\
\text { Methyldopa } \\
\text { Labetalol } \\
\text { Digoxin, insulin } \\
\text { Spironolactone } \\
\text { Clonidine, hydralazine } \\
\text { Digoxin, clonidine, labetalol } \\
\text { Insulin } \\
\text { Digoxin } \\
\text { Spironolactone } \\
\text { Labetalol, minoxidil, propranolol } \\
\text { Clonidine } \\
\text { Hydralazine, digoxin, spironolactone } \\
\text { Digoxin, propranolol, hydralazine } \\
\text { Timolol, hydralazine } \\
\text { Digoxin }\end{array}$ \\
\hline
\end{tabular}

++ Suboedema. $++=$ Pitting oedema. $+++=$ Anasarca.

TABLE I I-Clinical data on patients in whom muzolimine was compared with frusemide

\begin{tabular}{|c|c|c|c|c|c|c|}
\hline $\begin{array}{l}\text { Case } \\
\text { No }\end{array}$ & $\begin{array}{l}\text { Age } \\
\text { (years) }\end{array}$ & Sex & $\begin{array}{l}\text { Creatinine } \\
\text { clearance } \\
(\mathrm{ml} / \mathrm{min})\end{array}$ & Renal disease & Associated conditions & Drugs \\
\hline $\begin{array}{l}21 \\
22 \\
23\end{array}$ & $\begin{array}{l}66 \\
18 \\
59\end{array}$ & $\begin{array}{l}\mathrm{F} \\
\mathrm{F}\end{array}$ & $\begin{array}{l}24 \\
19 \\
11\end{array}$ & $\begin{array}{l}\text { Nephrosclerosis } \\
\text { Lupus nephritis } \\
\text { Membranoproliferative glomerulonephritis }\end{array}$ & $\begin{array}{l}\text { Diabetes, cardiac failure } \\
\text { Cardiac failure, pleural effusion } \\
\text { Cryoglobulinaemia, cardiac failure }\end{array}$ & $\begin{array}{l}\text { Digoxin } \\
\text { Prednisone } \\
\text { Labetalol, prednisone, cyclophosphamide, } \\
\text { digoxin }\end{array}$ \\
\hline 24 & 52 & $M$ & 10 & Kimmelstiel-Wilson disease & Cardiac failure, pleural effusion & Digoxin \\
\hline
\end{tabular}

TABLE III-Effects of muzolimine on urinary excretory rates. (Figures are means $\pm S E M)$

\begin{tabular}{lcc}
\hline & $\begin{array}{c}\text { Basal } \\
\text { value }\end{array}$ & $\begin{array}{c}\text { With } \\
\text { muzolimine }\end{array}$ \\
\hline Urine volume (ml/day) & $1040 \pm 76$ & $1936 \pm 107^{*}$ \\
Urinary excretion (mmol/day) of: & $56 \cdot 7 \pm 6 \cdot 7$ & $154 \cdot 3 \pm 11 \cdot 9^{*}$ \\
Sodium & $24 \cdot 5 \pm 3 \cdot 2$ & $43 \cdot 4 \pm 3 \cdot 7^{*}$ \\
Potassium & $46 \cdot 5 \pm 5 \cdot 9$ & $139 \cdot 1 \pm 11 \cdot 1^{*}$ \\
Chloride & $4 \cdot 0 \pm 0 \cdot 2$ & $4 \cdot 1 \pm 0 \cdot 5$ \\
Calcium & $10 \cdot 3 \pm 3 \cdot 6$ & $8 \cdot 5 \pm 2 \cdot 2$ \\
Hydrogen & & \\
\hline
\end{tabular}

$* \mathrm{p}<0.0005$, paired $t$ test.

Conversion: SI to traditional units-Sodium, potassium, chloride, hydrogen: 1 $\mathrm{mmol} / \mathrm{day}=1 \mathrm{mEq} /$ day. Calcium $: 1 \mathrm{mmol} /$ day $=2 \mathrm{mEq} / \mathrm{day}$.

istration of muzolimine an appropriate period was allowed for stabilisation, which was considered to be satisfactory when body weight and plasma urea concentration were constant and the magnitude of changes in urinary sodium excretion did not exceed $20 \%$ in three consecutive days. In the last day of the stabilisation period basal 24-hour urine volume and urinary excretions of sodium, potassium, chloride, calcium, and hydrogen ions were measured. Plasma concentrations of sodium, potassium, chloride, and bicarbonate ions and urea, uric acid, and glucose were determined together with red and white blood cell counts and activities of aspartate and alanine transaminases. Body weight and supine blood pressure were measured and creatinine clearance calculated.

Muzolimine was started in a single daily dose given by mouth in the morning. Since this drug had not been used before in renal failure, the dosage was determined empirically for each patient using urine volume and salt excretion as guidelines. The initial dose was never lower than $1 \mathrm{mg} / \mathrm{kg}$ body weight; during treatment the dosage never exceeded $5 \mathrm{mg} / \mathrm{kg}$ body weight/day. Systemic blood pressure, body weight, and urinary excretory rates were monitored daily during treatment (experimental period) and for two days after the drug was stopped. Blood analyses and measurement of creatinine clearance were repeated at the end of the experimental period. In these studies any drug was stopped if this could be done without lessening medical care. Thus spironolactone was not stopped in some patients with nephrotic syndrome (cases 9, 14, and 17) and antihypertensive drugs were not stopped in cases of severe hypertension. These drugs, however, were maintained at the same dosage throughout the stabilisation and experimental periods.

\section{COMPARISON BETWEEN MUZOLIMINE AND FRUSEMIDE}

The effects of muzolimine and frusemide were compared in four patients (table II). All these patients required immediate and vigorous diuretic treatment because of severe fluid overload (anasarca) with respiratory distress due to cardiac failure or pleural effusion, or both. Thus high doses of intravenous frusemide were administered for one to two days. Since this treatment was unsuccessful, muzolimine was given in the hope of avoiding haemodialysis. Any drug treatment needed in addition to diuretics was continued unchanged during this study. Patients were maintained on a diet containing $20 \mathrm{mmol}(\mathrm{mEq})$ sodium daily; 24-hour salt and water excretions were noted the day before and during treatment with both diuretics.

Student's paired $t$ test was used for statistical analysis.

\section{Results}

\section{EFFICACY OF MUZOLIMINE}

Diuretic effects-In this study muzolimine was administered for a mean of 9.3 days. During treatment mean daily urinary output was about twice the basal value, excretions of sodium and chloride were almost three times the basal values, and potassium excretion was increased significantly, while only slight, non-significant changes were observed in calcium and hydrogen excretions (table III). The potency of the diuretic effect of muzolimine was further shown by the significant fall that occurred in mean body weight (from $73.3 \pm \mathrm{SE}$ 2.8 to $67.5 \pm 2.5 \mathrm{~kg}, \mathrm{p}<0.001)$ and by the complete disappearance of oedema in all affected patients. The increases in urine volume and salt excretion on the first and last days of treatment were similar. No rebound phenomenon was observed in the first two days after the drug was stopped (fig 2).

Effects on blood pressure-Treatment with muzolimine was followed by a decrease in blood pressure in all hypertensive patients. Mean blood pressure was normalised in five out of seven hypertensive patients given muzolimine alone and in 10 out of 11 patients in whom muzolimine was added to their previous antihypertensive treatment (fig 3).

Effects on blood composition-Treatment with muzolimine caused a rise in both urea and uric acid concentrations, while the plasma creatinine concentration and creatinine clearance remained unchanged. Serum chloride concentration was significantly reduced, while serum concentrations of bicarbonate, sodium, potassium, 
calcium, and glucose were not significantly modified (table IV). No pathological change occurred in red and white blood cell counts or serum transaminase activities.

Dosage-An inverse, though rough, correlation between dosage and creatinine clearance was found retrospectively. The mean daily dose was $1.8 \mathrm{mg} / \mathrm{kg}$ body weight in nine patients with creatinine clearances

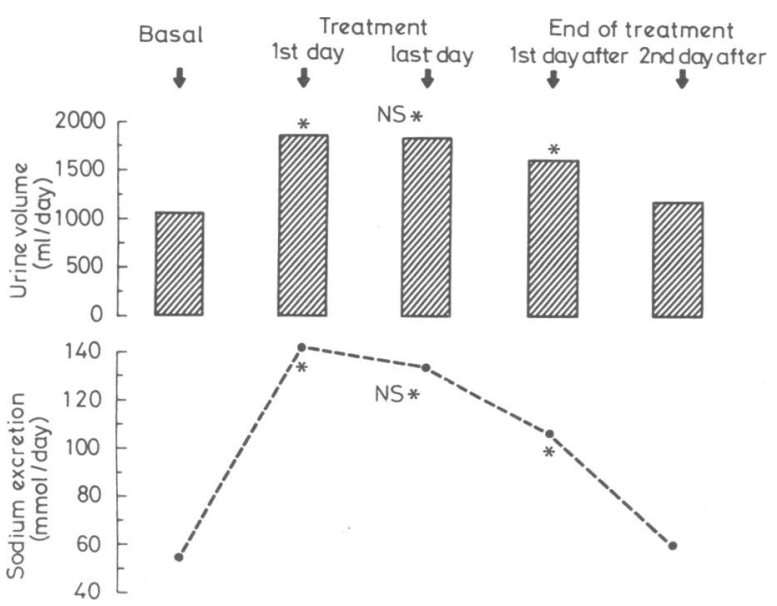

FIG 2-Mean urine volume and sodium excretion on first and last days of muzolimine administration and on first two days after end of treatment.

$* \mathrm{p}<0.001$ compared with basal value.

$\mathrm{NS}=$ Not significant when compared with result obtained on first day of treatment.

Conversion: $S I$ to traditional units-Sodium: $1 \mathrm{mmol} / \mathrm{day}=$ $1 \mathrm{mEq} /$ day.

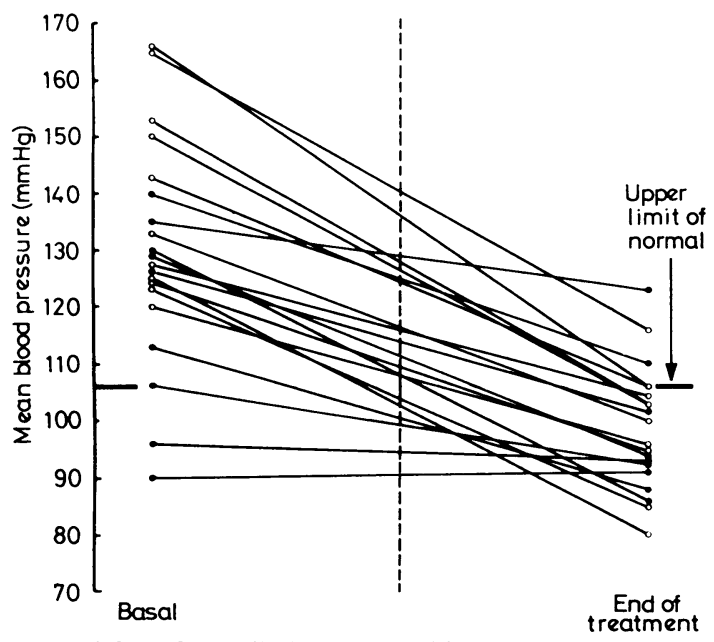

FIG 3-Effect of muzolimine on mean blood pressure.

- Patients treated with only muzolimine. $\mathrm{O}=$ Patients treated with muzolimine and other antihypertensive agents.

TABLE IV-Effects of muzolimine on plasma composition and creatinine clearance. (Figures are means $\pm S E M$ )

\begin{tabular}{lcc}
\hline & $\begin{array}{c}\text { Basal } \\
\text { values }\end{array}$ & $\begin{array}{c}\text { Values at } \\
\text { end of treatment }\end{array}$ \\
\hline Urea $(\mathrm{mmol} / \mathrm{l})$ & $25 \cdot 1 \pm 0 \cdot 3$ & $34 \cdot 6 \pm 0 \cdot 3+$ \\
Uric acid $(\mu \mathrm{mol} / \mathrm{l})$ & $452 \cdot 1 \pm 29 \cdot 7$ & $582 \cdot 9 \pm 23 \cdot 7 \dagger$ \\
Sodium $(\mathrm{mmol} / \mathrm{l})$ & $141 \cdot 1 \pm 0 \cdot 8$ & $139 \cdot 6 \pm 1 \cdot 1$ \\
Potassium $(\mathrm{mmol} / \mathrm{l})$ & $4 \cdot 5 \pm 0 \cdot 2$ & $4 \cdot 1 \pm 0 \cdot 1$ \\
Chloride $(\mathrm{mmol} / \mathrm{l})$ & $99 \cdot 6 \pm 0 \cdot 8$ & $95 \cdot 4 \pm 1 \cdot 9 *$ \\
Bicarbonate $(\mathrm{mmol} / \mathrm{l})$ & $24 \cdot 0 \pm 1 \cdot 4$ & $24 \cdot 5 \pm 1 \cdot 2$ \\
Calcium $(\mathrm{mmol} / \mathrm{m})$ & $1 \cdot 99 \pm 0 \cdot 75$ & $2 \cdot 06 \pm 0 \cdot 75$ \\
Glucose $(\mathrm{mmol} / \mathrm{l})$ & $4 \cdot 99 \pm 0 \cdot 33$ & $5.55 \pm 0.44$ \\
Creatinine $(\mu \mathrm{mol} / \mathrm{l})$ & $698 \cdot 4 \pm 176 \cdot 8$ & $583 \cdot 4 \pm 79 \cdot 6$ \\
Creatinine clearance $(\mathrm{ml} / \mathrm{min})$ & $16 \cdot 8 \pm 1 \cdot 5$ & $15 \cdot 8 \pm 1 \cdot 9$ \\
\hline
\end{tabular}

Significance of difference from basal values: ${ }^{*} \mathrm{p}<0.05 ; \dagger \mathrm{p}<0.001$ (paired $t$ test) Conversion: SI to traditional units-Urea: $1 \mathrm{mmol} / 1 \approx 6 \mathrm{mg} / 100 \mathrm{ml}$. Uric acid: $\mu \mathrm{mol} / 1 \approx 16 \cdot 8 \mu \mathrm{g} / 100 \mathrm{ml}$. Sodium, potassium, chloride, bicarbonate: $1 \mathrm{mmol} / \mathrm{l}=$ $\mathrm{mEq} / 1$. Calcium: $1 \mathrm{mmol} / 1=2 \mathrm{mEq} / 1$. Glucose : $1 \mathrm{mmol} / 1 \approx 18 \mathrm{mg} / 100 \mathrm{ml}$. Creatinine of $20-30 \mathrm{ml} / \mathrm{min}, 2 \cdot 4 \mathrm{mg} / \mathrm{kg}$ body weight in five patients with creatinine clearances of $10-19 \mathrm{ml} / \mathrm{min}$, and $4.6 \mathrm{mg} / \mathrm{kg}$ body weight in six patients with creatinine clearances below $10 \mathrm{ml} / \mathrm{min}$.

\section{COMPARISON WITH FRUSEMIDE}

Muzolimine raised sodium excretion and urine output in all four patients previously treated unsuccessfully with frusemide (fig 4). Sodium excretion was $45.0 \pm \mathrm{SE} 16.5 \mathrm{mmol} / 24$ hours under basal conditions, $55 \cdot 8 \pm 18.4 \mathrm{mmol} / 24$ hours during administration of frusemide $(p>0.5)$, but $178.0 \pm 24.4 \mathrm{mmol} / 24$ hours $(p<0.05)$ during treatment with muzolimine.

This rise in sodium and water excretion reversed respiratory distress and appreciably reduced peripheral oedema, so that haemodialysis was no longer necessary.
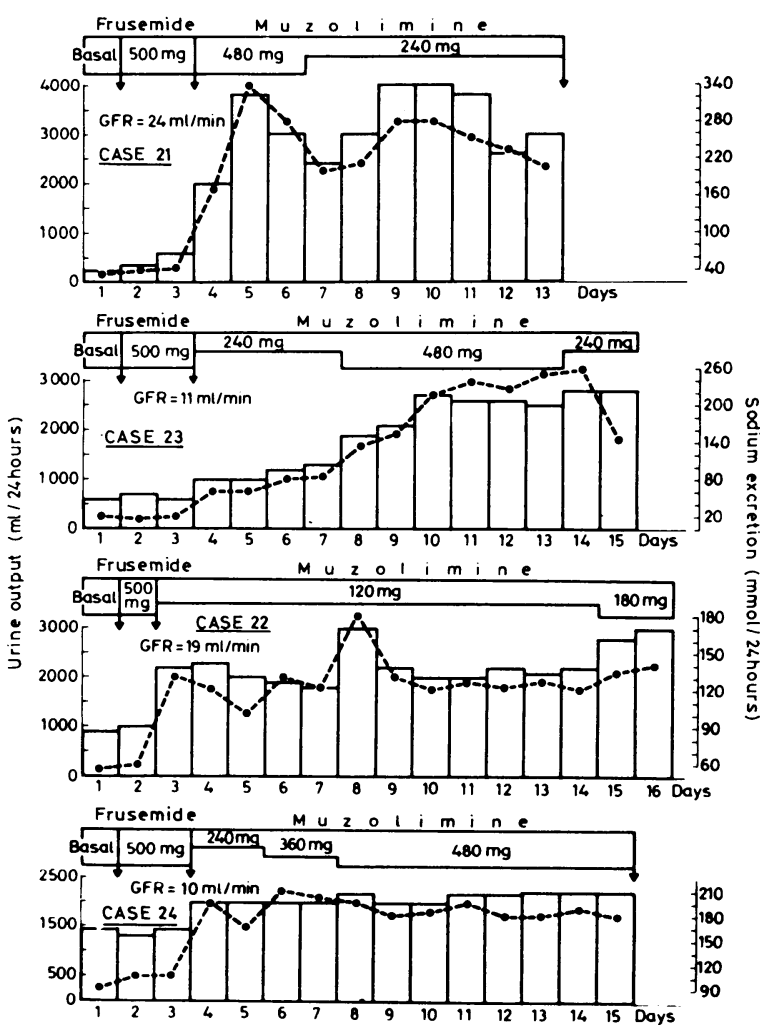

FIG 4-Effects of muzolimine on urine output and sodium excretion (• - - $\bullet$ ) in four patients previously treated with intravenous frusemide.

$\mathrm{GFR}=$ Glomerular filtration rate.

Conversion: SI to traditional units-Sodium: $1 \mathrm{mmol} / 24$ hours $=1 \mathrm{mEq} / 24$ hours.

\section{ADVERSE REACTIONS}

Muscle cramps occurred in three patients (cases 2, 3, and 19) in the final days of treatment but disappeared soon after the drug was stopped. Fasting blood glucose concentration increased from 4.88 $\mathrm{mmol} / 1(87.8 \mathrm{mg} / 100 \mathrm{ml})$ to $10.99 \mathrm{mmol} / 1(197.8 \mathrm{mg} / 100 \mathrm{ml})$ in a diabetic patient receiving insulin (case 12).

\section{Discussion}

It is widely accepted that salt retention and extracellular fluid volume expansion play a key part in the pathophysiology of hypertension secondary to chronic renal failure. ${ }^{8}{ }^{9}$ Hence the treatment of uraemic hypertension must rely on the correction of salt retention.

We normalised systemic blood pressure in our uraemic patients by increasing salt excretion with muzolimine; this occurred both in cases of previously untreated hypertension, 
when muzolimine was given alone (cases $2,5,9,12$, and 20), and in cases of severe hypertension refractory to conventional antihypertensive agents, when muzolimine was added to the treatment already being given (cases $3,4,6,7,10,11,15,16,18$, and 19).

Nephrotic syndrome, congestive heart failure (during the whole course of chronic renal failure), and the striking fall in urine output (in far-advanced chronic uraemia) are all responsible for salt retention and oedema requiring diuretic treatment. In all our uraemic patients with oedema administration of muzolimine resulted in complete resolution of the oedema; salt and water excretions increased considerably after adequate oral doses of the drug, despite creatinine clearances as low as $4 \mathrm{ml} / \mathrm{min}$.

This favourable diuretic effect was obtained with single daily doses of the drug taken by mouth usually in the morning. No rebound phenomenon occurred at the end of the treatment. No adverse reactions were observed, apart from muscle cramps in three patients presumably secondary to excessive salt depletion.

The increase in potassium but not calcium excretion after administration of muzolimine appears particularly advantageous in patients with advanced uraemia because of their tendency to hyperkalaemia and hypocalcaemia. The significant fall in serum concentration of chloride observed at the end of treatment may reflect a primary effect of the drug on chloride reabsorption in Henle's loop..$^{10}$

Renal function was not modified by muzolimine as shown by the constancy in creatinine clearance. Nevertheless, plasma concentrations of urea and uric acid were significantly increased, as is commonly observed after diuretic treatment in uraemic patients. This may be accounted for by a rise in tubular reabsorption of urea and uric acid secondary to the extracellular fluid volume contraction. A direct effect of the drug on tubular function, however, cannot be excluded.

These studies give convincing evidence that muzolimine is a potent diuretic extremely effective in treating salt retention in patients with advanced renal failure. It may even be preferable to other high-ceiling diuretics, such as frusemide: muzolimine given by mouth appeared to be effective in treating salt retention refractory to high intravenous doses of frusemide.

\section{References}

1 Yeh BPY, Tomko DJ, Stacy WK, Bear ES, Haden HT, Falls WF. Factors influencing sodium and water excretion in uremic man. Kidney Int $1975 ; 7: 103-10$.

${ }^{2}$ Allison MEM, Kennedy AC. Diuretics in chronic renal disease: a study of high dosage frusemide. Clin Sci $1971 ; 41: 171-87$

3 Maher JF, Schreiner GE. Studies on ethacrynic acid in patients with refractory edema. Ann Intern Med 1965;62:15-29.

4 Meng K. Zum renalen Wirkungsmechanismus der Diuretika. Dtsch Med Wochenschr 1970;95:2089-94.

5 Möller E, Horstmann H, Meng $\mathrm{K}$. The chemistry of muzolimine (Bay g 2821), a new non-sulphonamide diuretic. Pharmatherapeutica 1977; $1: 540-5$.

${ }^{6}$ Mussche M, Lameire N. The mechanism of action of Bay g 2821: a new diuretic. Curr Med Res Opin 1977;4:462-8.

7 Berg KJ, Jørstad S, Tromsdal A. Studies on the clinical pharmacology of a new potent diuretic, Bay g 2821. Pharmatherapeutica 1976;1:319-32.

${ }^{8}$ Massry SG, Sellers A, eds. Clinical aspects of uremia and dialysis. Springfield: C C Thomas, 1976.

- Early LE, Gottschalk CW, eds. Strauss and Welt's diseases of the kidney. Boston: Little, Brown and Co, 1979.

10 Loew D, Meng K. The renal mechanism of Bay g 2821. Pharmatherapeutica $1977 ; 1: 333-40$

(Accepted 19 November 1980)

\title{
Ipratropium bromide in acute asthma
}

\author{
M J WARD, P H FENTEM, W H RODERICK SMITH， D DAVIES
}

\begin{abstract}
Ipratropium bromide was given to patients admitted to hospital with acute asthma. A cumulative-dose-response technique in six patients showed that $500 \mu \mathrm{g}$ given by nebuliser produced a maximal increase in peak expiratory flow rate. This dose of ipratropium bromide was included in a regimen in which it was given either two hours before or two hours after nebulised salbutamol to 22 patients. Ipratropium bromide given on admission was as effective as nebulised salbutamol. The two drugs in sequence produced greater bronchodilatation than either used alone, and the mean peak expiratory flow rate rose by $96 \%$ in four hours.

Thus giving ipratropium bromide in addition to salbutamol in severe asthma enhances the bronchodilator effect. Further studies are needed to determine whether the same effect may be obtained by giving two maximal doses of salbutamol two hours apart.
\end{abstract}

Department of Thoracic Medicine, City Hospital, Nottingham

$M$ J WARD, MRCP, research registrar

P H FENTEM, MSC, MB, professor of physiology

W H RODERICK SMITH, MB, consultant physician

D DAVIES, MD, FRCP, consultant physician

\section{Introduction}

Inhaled atropine-like compounds are useful in treating airflow obstruction in chronic bronchitis and asthma. The latest preparation available is ipratropium bromide. It produces appreciable bronchodilatation but, on the whole, not as much as salbutamol. Ipratropium bromide and salbutamol in combination have an additive effect, ${ }^{1}$ but some studies have failed to show this. ${ }^{23}$ In these trials ipratropium bromide was given from a pressurised aerosol to patients with asthma, but not during an acute attack. Bronchodilators given from aerosol canisters are not particularly effective in severe asthma, but when given by nebuliser without positive pressure they are as effective as when given intravenously. ${ }^{45}$ We studied the use of nebulised ipratropium bromide in acute asthma and compared it with nebulised salbutamol.

\section{Patients and methods}

We studied 28 patients (18 women and 10 men) aged 15-79 years admitted to hospital with an acute attack of asthma. Twenty-one were atopic. All had an arterial oxygen pressure of under $9.3 \mathrm{kPa}(68 \mathrm{~mm}$ $\mathrm{Hg}$ ) and a peak expiratory flow rate of less than $25 \%$ of the predicted value. Measurements of peak expiratory flow rate were made throughout with a Wright peak flow meter, the best of three readings being taken.

Selection of the dose of ipratropium bromide-A cumulative-dose 